\title{
PENENTUAN JARAK TEMBAK BERDASARKAN KERUSAKAN PROYEKTIL TIMAH TANPA JACKET UNTUK SENJATA API GENGGAM JENIS REVOLVER S\&W KALIBER .38 SPESIAL PADA TARGET TULANG
}

\author{
Sudibyo $^{* 1}$, Suhariningsih ${ }^{2}$, Sunarjo $^{3}$ \\ Prodi S2 Ilmu Forensik, Sekolah Pascasarjana Universitas Airlangga Surabaya \\ Kampus B Unair, Jl. Airlangga nomor 4 - 6 Surabaya, Indonesia. \\ Email : sudibyomanguntari@yahoo.com
}

\begin{abstract}
This study aims to predict the shooting range based on damage the type of lead a projectile without jacket caliber.38 special fired from handguns kinds brand Revolver $S \& W$ caliber .38 specials. Based on the phenomenon of criminal cases of abuse handguns types Revolver and the fact that real data it was found that $8 \%$ of the amount of lead projectiles without jacket as forensic evidence, the condition has broken the deformed moderate to severe.

The study was conducted at the Police Forensic Laboratory experimental method test-fired in the shooting box at short throw distance range of 0.5 to 6 meters, where the bone is positioned at the target position changes location every 0.5 meters, so the total number of shots is 12 times shot on 12 position target location, and finally obtained 12 variations of deformation projectile shot results.

Stages test firing conducted through three stages as follows: 1). Phase sample preparation equipment and materials firearms, bullets and target bone. 2). Phase shooting target accurately. 3). Stages of deformation measurements and weighing projectile, arranged in the form of table data.

Material samples of bullet used was the type of lead bullets without jacket caliber .38 special with technical specifications diameter of projectile $9.09 \mathrm{~mm}$ (real $9.05 \mathrm{~mm}$ ), length of projectile $17.90 \mathrm{~mm}$ (real $18.61 \mathrm{~mm}$ ), projectile material lead antimony, projectile weight of 10.25 grams, muzzle velocity (initial) $265 \mathrm{~m} /$ sec, rounded nose shape, coefficient of form $C=2$, the ballistic coefficient $i=0,9$ effective range or the distance accurately of 25 meters.

Material samples of bone were used as target is 1694 SR veal ribs with bone hardness values $(87 \pm 1.5)$ shore, is used for the calibration test firing, a human skull age adults ( $\geq 35$ years) with a value of hardness (78 \pm 6 ) shore, is used as the target subjects of research, human ribs (costal C-3 / C-6) adult ( $\geq 35$ years) with a value of hardness $(69 \pm 19.5)$ shore, is used as the target subjects of research.
\end{abstract}

Keywords : deformation; projectiles; bones.

\section{PENDAHULUAN}

Latar belakang masalah :

a. Adanya fenomena kasus penyalah gunaan senjata api jenis Revolver dengan korban meninggal dunia, dimana dalam persidangan Pengadilan Negeri Magetan 2012 dipertanyakan kondisi fisik BB proyektil yang terdeformasi bila dihubungkan dengan jarak tembaknya yaitu dari pengalaman peneliti. b. Jumlah kasus senjata api jenis Revolver yang masuk diperiksakan ke Labfor Polri Cabang Surabaya dalam kurun waktu 5(lima) tahun 2009-2013 paling tinggi persentasinya, yakni $64 \%$. Jumlah kasus dapat dilihat dari data kasus di Labfor Polri Cabang Surabaya.

c. Belum pernah dilakukan penelitian sebelumnya, berkaitan dengan penentuan jarak tembak senjata api jenis Revolver berdasar kerusakan fisik proyektil .Data 
sebelumnya berasal dari Journal internasional asosiasi pemeriksa forensik senjata api.

d. Penentuan jarak tembak berdasar kerusakan proyektil untuk senjata api genggam jenis Pistol dengan peluru tipe parabellum $9 \mathrm{~mm}$ FMJ pada target sasaran dinding tembok beton sudah pernah dilakukan./(F. Bresson).

\section{Rumusan Masalah}

Rumusan masalah dari fenomena yang diangkat dalam topik penelitian ini adalah bagaimanakah cara menentukan jarak tembak berdasarkan kerusakan proyektil timah tanpa jacket untuk senjata api genggam jenis revolver S\&W kaliber .38 spesial, pada target sasaran tulang, serta bagaimanakah perbandingan skor deformasinya antara jenis target sasaran tulang rusuk dan tulang tengkorak manusia.

\section{TINJAUAN TEORI}

Senjata api Revolver adalah senjata api genggam atau senjata api ringan dengan bentuk rancang bangun (design) sistem mekanik menggunakan blok silinder berputar sebagai kamar senjata (kamar peluru) dan satu laras (barrel), yang memungkinkan penggunanya dapat melakukan penembakan secara berurutan satu per satu peluru sesuai dengan jumlah atau kapasitas peluru yang terdapat didalam silinder. Pada setiap kali pelatuk (trigger) ditarik maka sistem ekstraktor akan bekerja dengan berputarnya silinder untuk menggulirkan kamar senjata yang berisi peluru siap tembak selaras dengan posisi lubang laras (barrel) senjata dan pena pengapian (firing pin). Paling umum kapasitas silinder adalah 5 atau 6 butir peluru, walaupun ada juga yang berkapasitas 7 sampai 10 butir peluru dari jenis Revolver klasik. /(George Martin, 1989).

Terdapat cukup banyak varian merk, model dan kaliber senjata api genggam jenis Revolver tersebut sesuai dengan perkembangan jaman, mulai dari model klasik sampai yang modern. Adapun dari sekian jumlah merk yang paling populer di Indonesia adalah merk Colt, Smith \&Wesson, Taurus, Ruger, Remington, Baretta dan Magnum.

Beberapa faktor yang berpengaruh pada kecepatan proyektil saat ditembakkan dari senjata api, antara lain : koefisien bentuk proyektil, koefisien balistik proyektil, stabilitas giroskopik, tingkat alur putaran dalam laras senjata (twist) dan kecepatan ledakan di moncong (ujung selongsong) peluru./ (W.J.Stronge, 2015).

Struktur tulang secara alami (biologi) terdiri dari : bagian luar adalah lapisan tulang keras (matrik kompak), sedang bagian dalam terdiri dari tulang beronga (sponge). Sel induk tulang (osteoblast) menghasilkan matrik tulang yang di dalamnya diendapkan garam-garam kalsium (Ca) dan phospor (P) sehingga tulang menjadi keras.

Berbeda dengan tulang pipa yang memiliki sisi keras pada lingkar luar yang rata sesuai bentuk dan posisinya yang berada dalam jaringan (tissue), tulang tengkorak (kranium) yang berfungsi untuk melindungi otak memiliki sisi keras di bagian luar yang relatif rata, sedang bagian dalam permuakaannya berbentuk relif bergelombang sesuai dengan bentuk relif jaringan otak./(Raven and Johnson).

Secara teoritis fakta deformasi proyektil adalah merupakan hasil dari interaksi mekanisme proses tumbukan antara material proyektil yang memiliki massa dan kecepatan, terhadap benda keras target sasaran yang diam atau bergerak dan memiliki massa. Sedang kecepatan proyektil akan semakin melemah selaras dengan jarak yang ditempuh dan hambatan yang dilalui. Sehingga nilai momentum tumbukan pada target sasaran akan melemah sesuai nilai kecepatan dari seberapa jauh jarak lintasan dan hambatan yang telah dilaluinya.

Teori ilmu fisika yang berlaku dalam penelitian ini adalah hukum Newton tentang mekanika gerak proyektil pada tumbukan terhadap benda keras yang kaku dan tidak lenting (statis). Dalam metode deformasi dan penetrasi, dua macam proses deformasi dan penetrasi proyektil ini dapat dihitung berturut-turut, dengan kenaikan waktu singkat. Dalam setiap langkah solusi deformasi, permukaan target diasumsikan kaku dan proyektil berubah bentuk tanpa penetrasi, kenaikan deformasi proyektil dan penurunan kecepatannya dapat dihitung. Dalam langkah berikutnya (penetrasi), proyektil diasumsikan kaku dan menembus ke target, dan peningkatan penetrasi proyektil yang kaku dapat dihitung./(H.Khodarahmi, 2004). 


\section{METODE PENELITIAN}

Penelitian ini termasuk jenis penelitian eksperimen dengan rancangan penelitian percobaan murni, sebagai cara untuk pengumpulan data angka (kuantitatif) dan bertujuan untuk menjelaskan (eksplanasi) sifat hubungan asimetris (pengaruh) perlakuan sebab akibat antara jarak tembak pada target sasaran tulang, terhadap efek tampilan (profil) deformasi proyektil yang memiliki karakteristik khusus.

Penelitian dilaksanakan pada bulan Mei 2015, bertempat di Laboratorium Forensik Bareskrim Polri Cabang Surabaya yang berada di dalam lingkungan Markas Polda Jatim Jl. A. Yani 116 Surabaya Jawa Timur.

Langkah-langkah pelaksanaan Uji penembakan dilakukan dengan urut-urutan sebagai berikut :

1. Tahap persiapan :

a. Persiapan peralatan meliputi pengecekkan senjata api sebagai alat penembak, shooting box serta alat bantu pengamanan operasional.

b. Persiapan bahan meliputi sampel tulang yang telah dipilih, dan luas bidang permukaan sampel yang akan dibidik.

c. Melakukan pengukuran jarak tembak dalam shooting box, kemudian memasang bantalan kapas pada letak sampel tulang, yakni pada bagian bawah dan belakang sampel tulang.

d. Memastikan posisi letak sampel tulang tepat berada di tengah dan segaris lurus (horisontal) bila dipandang dari bagian ujung depan shooting box.

2. Tahap penembakan :

a. Senjata api revolver dipastikan dalam kondisi kosong tanpa peluru, kemudian diisi 1(satu) butir peluru tajam.

b. Membidik dan menembak target sasaran dari arah ujung depan shoting box dengan sudut datar tegak lurus target sasaran.

c. Memeriksa akurasi posisi perkenaan tembakan pada target sasaran, dengan cara mencermati fakta bekas tumbukan proyektil pada target sasaran.

d. Bila fakta fisik bekas tumbukan pada target sasaran menunjukkan karakterisrik hasil tumbukan tegak lurus maka hasil tembakan telah sesuai dengan yang diharapkan dan tidak diperlukan pengulangan penembakan.

3. Tahap pengukuran hasil penembakan : a. Proyektil hasil tembakan yang bersarang pada kapas di sekitar lokasi target sasaran, diambil dan diamati bentuknya, kemudian dilakukan pengukuran deformasinya, yakni dengan cara menugukur panjang rata-rata proyektil setelah tumbukan menggunakan jangka sorong.

b. Menimbang berat akhir proyektil setelah tumbukan, dengan tujuan untuk mengetahui jumlah masa/berat sisa proyektil setelah proses tumbukan dan masa/beratnya yang hilang.

c. Mengukur diameter akhir proyektil setelah tumbukan, dengan tujuan untuk mengetahui perubahan diameter proyektil akibat tumbukan

Sketsa pelaksanaan uji penembakan :

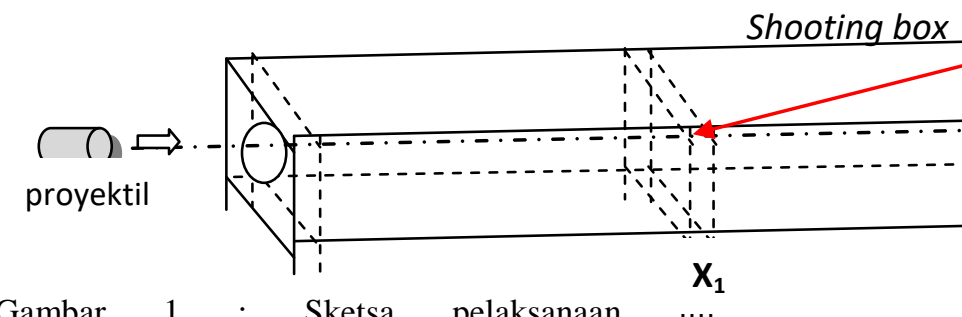
penembakan, $\mathrm{X}_{1}, \mathrm{X}_{2}, \ldots \mathrm{X}_{3}$ adalah variasi jarak target sasaran dalam shooting box.

Skala konversi nilai skor deformasi proyektil :

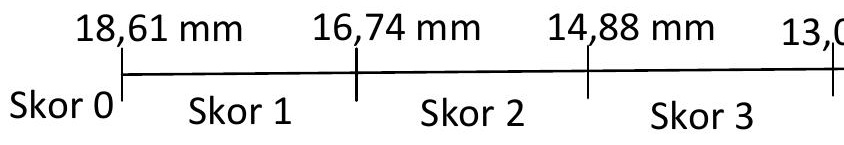

Gambar 2 :
Range skala konversi skor
deformasi proyektil.

d. Mengukur diameter rata-rata lubang penetrasi dan atau jejak tumbukan (impact) proyektil pada target sasaran, dengan tujuan untuk mengetahui perubahan diameter lubang penetrasi dan impact pada setiap jarak tembak.

e. Mengukur ketebalan rata-rata lubang penetrasi dan atau impact proyektil pada target sasaran untuk setiap jarak tembak.

4. Tahap pembuatan tabel data hasil pengukuran deformasi proyektil dari uji tembak dan 


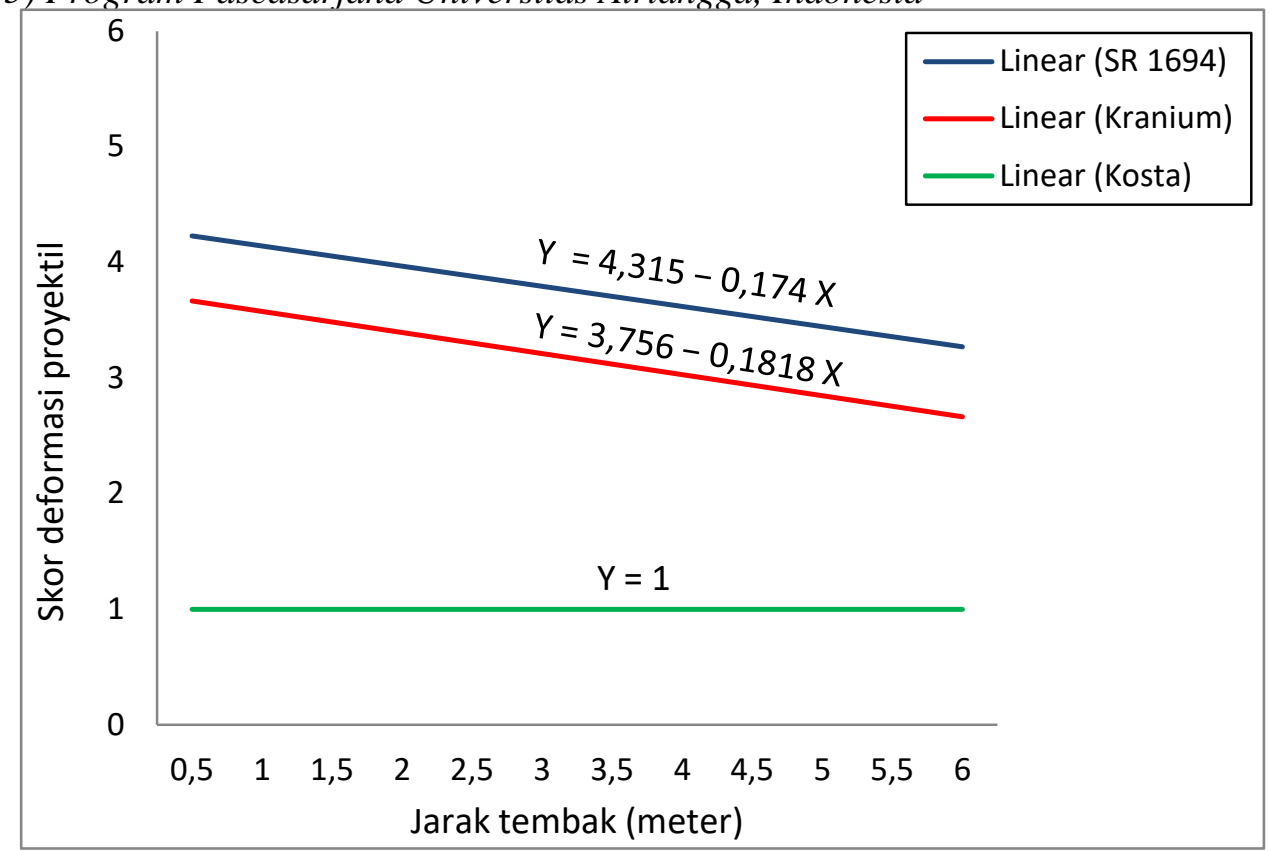

melakukan konversi nilai pengukuran rata-rata

ke nilai skoring. (disajikan pada Gambar 2).

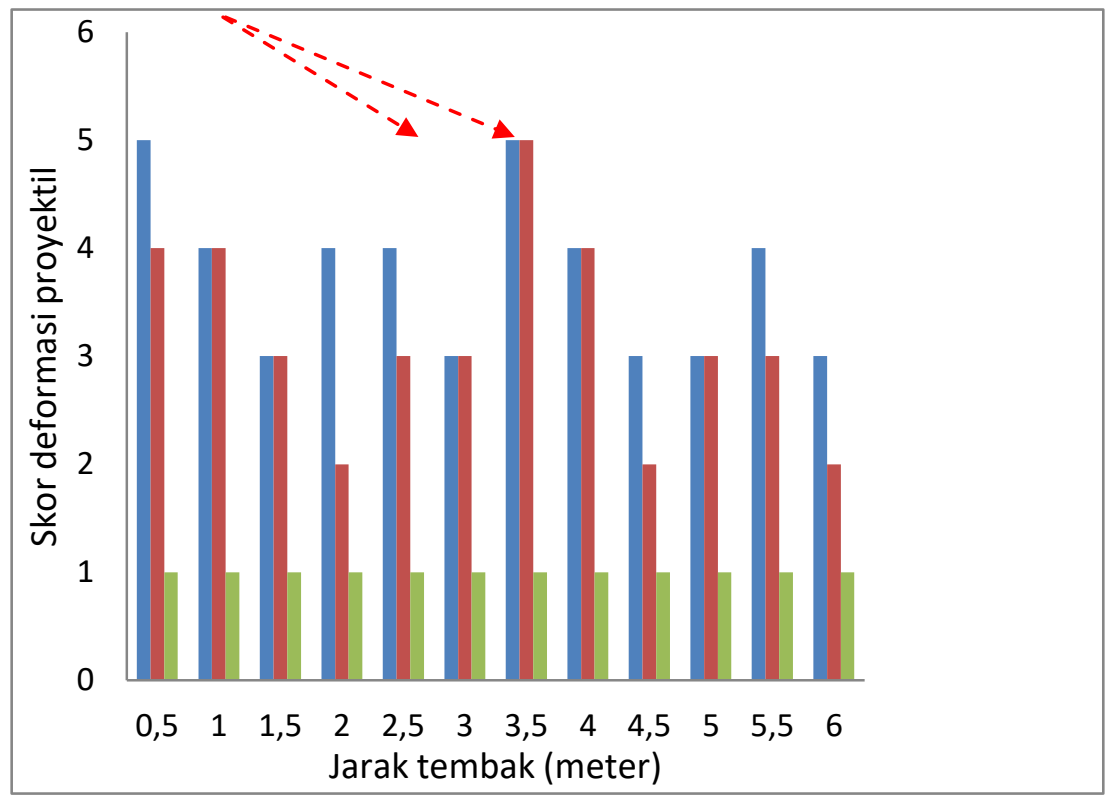

5. Pengujian data hasil uji tembak dengan analisis regresi linier, setelah terlebih dahulu dilakukan uji korelasi individu dan korelasi ganda antar variabel bebas dan variabel tergantungnya.

6. Menghitung nilai-nilai : mean, modus, median, standar deviasi dan koefisien korelasi, untuk mengetahui jenis datanya.

H A S I L :

Hasil penelitian didapatkan bahwa jarak tembak berpengaruh terhadap deformasi proyektil pada nilai kekerasan target sasaran tulang (78 \pm 6 shore) s/d $(87 \pm 1,5$ shore $)$ dan tidak

\section{Gambar 3 :}

Kurva perbandingan regresi linier nilai skor deformasi proyektil. 
Gambar 4 :

Diagram batang perbandingan

nilai skor deformasi proyektil.

dan tidak berpengaruh pada target sasaran tulang dengan nilai kekerasan (69 $\pm 19,5$ shore $)$, sebagaimana disajikan pada Gambar 3 dan Gambar 4.

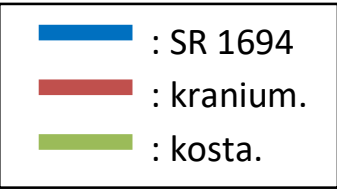

\section{PEMBAHASAN}

a. Sampel tulang SR 1694, dengan nilai ketebalan $10 \mathrm{~mm}$ dan nilai kekerasan $87 \pm 1,5$ shore, proporsi pengaruh jarak tembak terhadap deformasi proyektil $17,4 \%$.

b. Sampel tulang tengkorak (kranium) manusia, dengan nilai kekerasan $78 \pm 6$ shore, proporsi pengaruh jarak tembak terhadap deformasi proyektil 12,2\%, dan proporsi pengaruh perubahan ketebalan tulang $2,43 \%$.

c. Sampel tulang rusuk (kosta C-3/C-6) manusia, dengan nilai kekerasan $69 \pm 19,5$ shore, proporsi pengaruh jarak tembak terhadap deformasi proyektil $0 \%$, dan proporsi pengaruh perubahan ketebalan tulang $0 \%$. Jadi deformasi proyektil pada target sasaran tulang rusuk manusia ini $30,6 \%$ hanya dijelaskan melalui varian jenis tulang.

\section{KESIMPULAN DAN SARAN}

Berdasarkan analisis regresi linier dan pembahasan hasil penelitian, maka dapat ditarik kesimpulan penelitian sebagai berikut :

a. Jarak tembak untuk senjata api genggam Revolver S\&W kaliber .38 spesial dengan peluru jenis timah tanpa jacket, proporsinya rendah, hanya $12,2 \%$ pada target sasaran tulang tengkorak manusia.

b. Jarak tembak untuk senjata api genggam Revolver S\&W kaliber .38 spesial dengan peluru jenis timah tanpa jacket, proporsinya $0 \%$ atau tidak mempengaruhi deformasi proyektil pada target sasaran tulang rusuk manusia.

c. Aplikasi perkiraan jarak tembak dari sebutir barang bukti forensik, berupa proyektil yang terdeformasi, untuk senjata api Revolver S\&W kaliber .38 spesial dengan peluru timah tanpa jacket, pada target sasaran tulang tengkorak manusia usia dewasa ( $\geq 35$ tahun) dapat dihitung dengan persamaan sebagai berikut :

$\mathrm{Y}=3,756-0,1818 \mathrm{X}$------ persamaan (1), atau dengan persamaan :

$\mathrm{Y}=-14,34+5,8 \mathrm{X}_{1}-0,157 \mathrm{X}_{2}$--persamaan(2).

Dimana : $\mathrm{Y}$ : skor deformasi proyektil.

$\mathrm{X}, \mathrm{X}_{1}$ : jarak tembak.

$\mathrm{X}_{2}$ : tebal target sasaran.

d. Penentuan jarak tembak tersebut, dapat juga dengan cara intrapolasi dan ekstrapolasi menggunakan Gambar 3 dan Gambar 4.

Banyak hal dapat dilakukan untuk koreksi dan penyempurnaan maupun pengembangan pada penelitian ini, karena masih terbuka peluang $82,6 \%$ s/d $87,8 \%$ untuk dapat dijelaskan oleh variabel lain.

\section{UCAPAN TERIMAKASIH}

Ucapan terima kasih yang tak terhingga penulis haturkan kepada Yth. Wakil Direktur Bidang Akademik Sekolah Pascasarjana Universitas Airlangga Prof. Dr. Ir. Suhariningsih, selaku pembimbing Ketua penelitian tesis ini, dan Yth. Dr. Sunarjo, dr., M.S., M.Sc., selaku pembimbing kedua.

\section{DAFTAR PUSTAKA}

Brian J. Heard,. 2008. Handbook of firearms and ballistics. UK: John Wiley and Sons. Ltd.

Frank C. Barnes, Stan Skinner, 2006. Cartridges of the World. $11^{\text {th }}$ edition, USA : Published by Gun Digest Books, page 290.

George Martin., 1989. NRA FIREARMS Fact Book. Third edition. Washington DC: The National Rifle Association of America. pages 31-51, 60, 65-70, 196, 201, 224, 234-238.

Julian S. Hatcher., 1952. A Standard Reference Book for Shooters, Gunsmiths, Ballisticians, Historians, Hunters and 
Collectors. Third edition, Harrisburg, Pennsylvania, USA: Printed by The Telegraph Press, pages 232, 279-300, 394, 396, 399, 405, 422, 431.

J. Corner, 1950. Theory of the Interior Ballistics of Guns. New York: Copyright by John Wiley \& Sons, INC, pages 1-18, 327, 400.

K.G. Rakvag, ${ }^{\mathrm{a}}$, T. Bqrvik ${ }^{\mathrm{b}}$, I. Westermann ${ }^{\mathrm{a}, \mathrm{c}}$, O.S. Hopperstad a, 2013. "An Experimental study on the deformation and fracture modes of steel projectiles during impact." International Journal of Material \& Design, volume 51, oktober 2013, pages 242-256.

Lucien C. Haag,. 2006. Shooting Incident Reconstruction. London: Academic Press publications of Elsevier, pages 6167, 229-232.

Michael G. Haag, Lucien C. Haag., 2011. "Projectile Penetration an Perforation." International Journal of Shooting Incident Reconstruction, second edition, 13 May 2011, pages 105-124.

Michael G. Haag, Lucien C. Haag., 2011. "Determining Bullet Track ("Trajectory") in Gunshot Victims." International Journal of Shooting Incident Reconstruction, second edition, 13 May 2011, pages 191-205.

Moh. Nazir., 2011. Metode Penelitian. Ed 7, Bogor: Penerbit Ghalia Indonesia, hlm 510-544.

Moleong, Lexy J., 2011. Metodologi penelitian kualitatif. Ed 29, Bandung: PT. Remaja Rosdakarya Offset, hlm

Myrtati Dyah Artaria., 2008. Metode pengukuran manusia. Ed 1, Surabaya: Penerbit Airlangga University Press, hlm 66.

PT. PINDAD INDONESIA., 2002. Catalogue Military Product. Bandung: PT. PINDAD INDONESIA, halaman 34 dan 50.

Rini Indriastuti., 2012. Penyajian Data Statistik. Ed 1, Yogyakarta: PT. Citra Aji Parama, hlm 75-76.

Sugiyono., 2012. Statistika untuk Penelitian. Ed 20, Bandung: Penerbit CV. ALFABETA, hlm 368-389.

Townsend Whelen., 1946. Small Arms Design And Ballistics. Volume II, Georgetown,
South Carolina USA : Copyright by Thomas G. Samworth all rights reserved, pages $1-187$.

W.J.Stronge., 2015. "Impact perforation of monolithic polyethylene plate: Projectile nose shape dependence." International Journal of impact engineering, volume 80, pages 162-176. 